\title{
IMPRENSA POLÍTICA E PENSAMENTO REPUBLICANO NO PARANÁ NO FINAL DO XIX
}

\author{
Amélia Siegel Corrêa
}

\begin{abstract}
RESUMO
A crise do regime monárquico brasileiro veio acompanhada do surgimento e da expansão do movimento republicano, no final do século XIX. No período, a imprensa não somente colocou-se como palco dos debates institucionais, como também teve papel de poder informal, vinculado ao governo e à organização partidária. Tratava-se de uma imprensa de opinião, que tinha como um de seus eixos os comentários partidários. As colunas dos jornais eram usadas para escrever anonimamente o que não podia ser dito publicamente na Assembléia, Senado ou Câmara, constituindo um fórum de discussão alternativo à tribuna. Este artigo busca recuperar os modelos de República que circularam nesses periódicos paranaenses, relacionando-os com as configurações nas quais estavam inseridos e com a posição que ocupavam no campo do poder local e nacional. Todavia, vale lembrar que os ideários republicanos dominantes não foram disseminados sem resistência no Paraná; ao contrário, foram detectados e combatidos localmente, porém sem força política suficiente. Parte-se da perspectiva bourdiesiana de que os discursos não são unicamente signos destinados a serem compreendidos e decifrados, mas também indicativos de status, que se propõem a ser valorados e apreciados, e de autoridade, a serem cridos e obedecidos, por constituírem um objeto da luta simbólica pelo poder. A análise dos discursos republicanos mostra que a política paranaense do final do século XIX era mais um resultado de alianças e desavenças entre grupos do que fruto de posicionamentos ideológicos. Os discursos serviam, majoritariamente, como armas retóricas utilizadas para orientar o enfrentamento intra-elites, movido pelo desejo de participação, o que fez com que tivesse um caráter genérico, alicerçado na concepção do fim dos privilégios, embora sem a ampliação da cidadania.
\end{abstract}

PALAVRAS-CHAVE: republicanismo; Paraná; imprensa política; federalismo; campo político.

\section{INTRODUÇÃO}

Há uma grande tradição de análise sobre o movimento republicano brasileiro da segunda metade do século XIX ${ }^{1}$, sobretudo no que se refere à atuação das elites e à importação de idéias européias, com suas diferentes cores e feições regionais. A intenção deste artigo ${ }^{2}$ é participar desse debate, apresentando um panorama dos ideários republicanos debatidos no Paraná, ou seja, das concepções de regime político que estavam em

\footnotetext{
1 Ver, por exemplo, Holanda (1985), Carvalho (1990; 1996), Costa (1999), Alonso (2002) e Gomes (2002).

2 Este artigo é fruto da Dissertação de Mestrado de minha autoria, intitulada Imprensa e política no Paraná: prosopografia dos redatores e pensamento republicano no final do século XIX, apresentada ao Programa de PósGraduação em Sociologia, da Universidade Federal do
} Paraná, em 2006. disputa naquele contexto. Dessa forma, esse trajeto de contestação do regime monárquico e de implantação do regime republicano será feito por meio das discussões veiculadas pela imprensa, com o intento de apreender os posicionamentos políticos e ideológicos concernentes a tal temática no Paraná. Como se sabe, a imprensa, durante o período imperial (pode-se dizer que até os primeiros anos da República), era um foro de poder informal, vinculado ao governo e à organização partidária. Tratava-se de uma imprensa de opinião, que tinha como um de seus eixos os comentários partidários. Havia folhas independentes que duravam pouco, pois a "grande maioria era vinculada a partidos ou a políticos” (CARVALHO, 1996, p. 46). As colunas dos jornais eram usadas para escrever anonimamente o que não podia ser dito publicamente na Assembléia, Senado ou Câmara, constituindo um fórum de discussão alternativo à tribuna. 
O objeto deste artigo situa-se no momento em que a imprensa tornou-se o principal palco para as discussões e para a luta política, em detrimento dos limites constitucionais. O objetivo, com isso, é melhor identificar as propostas de regime político, democracia e participação popular apresentadas pelos redatores. Considerando esse recorte, minha intenção foi recuperar os ideários republicanos que circulavam nos jornais paranaenses, a fim de reconstituir suas tendências e reivindicações, bem como o posicionamento e as articulações do pensamento político regional no campo político nacional. Parte-se da perspectiva bourdieusiana de que os discursos não são unicamente signos destinados a serem compreendidos e decifrados, mas também indicativos de status, que se propõem a ser valorados e apreciados, e de autoridade, a serem cridos e obedecidos, por constituírem um objeto da luta simbólica pelo poder (BOURDIEU, 2001, p. 40).

O Paraná do século XIX contava com duas elites econômicas que detinham o poder político do estado: as elites rurais dos Campos Gerais e a burguesia ervateira de Curitiba e do litoral. Esta tomava cada vez mais o espaço daquela, principalmente após a Guerra do Paraguai, quando a produção da erva-mate expandiu-se para atender ao mercado platino, aumentando seu capital político e econômico ${ }^{3}$. Concomitantemente, a decadência do tropeirismo e o advento das ferrovias levavam as elites tradicionais a um processo de decadência econômica; essa perda de capital econômico reverberava no campo político ${ }^{4}$. Os partidos Conservador ${ }^{5}$ e Liberal ${ }^{6}$ imperiais tinham sua

\footnotetext{
3 Contudo, mesmo com a consolidação de uma burguesia exportadora, as elites paranaenses continuaram marginalizadas em nível nacional.

4 Os conceitos de campo, habitus e capital foram retirados de Bourdieu (2003), para quem os atores sociais estão inseridos espacialmente em determinados campos sociais, em que a posse de certos capitais (cultural, social, econômico, político etc.) e o habitus de cada ator condicionam a sua posição no campo. A idéia de campo aqui utilizada refere-se, na maioria das vezes, ao campo político, ou do poder, aos quais os jornais, redatores e respectivos grupos estavam vinculados, assim como com as idéias republicanas que proferiam, fruto da posição que ocupavam.

5 O Partido Conservador era comandado por dois dos mais poderosos exportadores de erva-mate da província: o Visconde de Nácar, representante das oligarquias do litoral paranaense, e Ildefonso Correia, futuro Barão do Serro Azul, também oriundo de família ilustre do litoral, cujo irmão era
}

composição social nessas elites ervateiras e rurais, respectivamente. Os conservadores, por seu crescente capital econômico, buscaram constituir o seu poder para além de interesses imediatos, e investiram na criação de um meio editorial mais complexo, com jornais, tipografias etc. ${ }^{7}$

Entrementes, nesse final do século XIX, uma singela movimentação republicana surgia na província, por meio de dois núcleos irradiadores: o litoral, principalmente Paranaguá, e Curitiba. Esse movimento foi muito fraco se comparado ao de outras províncias, o que indica o conformismo das elites locais com o regime monárquico. Reflexo dessa assertiva está no fato de os primeiros presidentes dos clubes republicanos dessas cidades terem vindo de fora: Guilherme Leite ${ }^{8}$, presi-

senador e membro da elite política imperial em seu primeiro escalão. Ocupavam a posição dominante no campo econômico regional, mas sofriam sérios entraves na Assembléia, dominada pelos liberais durante o período monárquico.

6 O Partido Liberal, representante das elites agrárias, tinha sua produção mais voltada para o mercado interno. Porém, com a crise de sua posição no campo econômico, cada vez mais dominado pelos ervateiros, unido à configuração do jogo político nacional, com a hegemonia saquarema, a posição dos grandes proprietários ligados ao tropeirismo e à pecuária foi ficando cada vez mais dominada, embora desafiasse com freqüência a hegemonia dos conservadores, obstruindo a aprovação de suas demandas na Assembléia. O principal órgão do partido foi o Dezenove de Dezembro, primeira folha impressa no Paraná. Após a Proclamação da República, aceitaram os fatos e aderiram ao governo provisório

7 A burguesia ervateira, na figura do Barão do Serro Azul, fez inúmeros investimentos para a criação de um campo de produção cultural, adquirindo a Impressora Paranaense, antiga Tipografia Lopes (a primeira da província) e a Litografia do Comércio. Logo, serviam não só para a produção dos rótulos, mas também para fomentar a imprensa, área estratégica dos investimentos do Barão.

8 Nascido em Recife, em 1855, chegou a Paranaguá em 1880, onde desenvolveu atividades no comércio local. Logo se fez amigo de Fernando Simas, a quem revelava seus ideais antimonarquistas, em combate ao governo imperial. Era assíduo leitor dos jornais que circulavam naquela época no Brasil e no estrangeiro. Foi o primeiro presidente do Clube Republicano de Paranaguá, tendo recebido, por esse acontecimento histórico, expressivos telegramas de congratulações de Silva Jardim, Quintino Bocaiúva, Ubaldino do Amaral e Prudente de Moraes (FIGUEIRA, 1948, p. 11-12). Fernando Machado Simas nasceu em Paranaguá, em 1851, e formou-se farmacêutico no Rio de Janeiro. Já em 1867, de volta à sua terra natal, publicava o jornal Imprensa Livre, no qual apresentava perspectivas democrá- 
dente do Clube de Paranaguá, fundado em 1887, era pernambucano, e Eduardo Gonçalves ${ }^{9}$, que estabeleceu o de Curitiba, em 1885, era paulista.

Os partidos monárquicos no Paraná praticamente não se envolveram nos debates republica$\operatorname{nos}^{10}$, e seus principais jornais, a Gazeta Paranaense (conservador) e o Dezenove de Dezembro (liberal), limitavam-se ao embate intra-elites, apenas eventualmente publicando alguma nota sobre o Clube Republicano, em que figurava certo menosprezo pelo movimento local, com suas propostas sendo consideradas sem propósito e desnecessárias: "Respeitamos as convicções de cada um, mas achamos que infelizmente o colega gasta o tempo com palavras, palavras e nada mais. Com isto diz Tavares Bastos com toda a razão, 'monarquia e república são puras questões de forma', apoiado em dois incontestáveis conceitos de pensadores de primeira ordem [...]. Querem mais República do que há no Brasil? Só se desejam ser candidatos à cadeira da Presidência” (NOTICIÁRIO, 1886). Essa atitude de reserva em relação ao movimento fica evidente também num artigo da folha conservadora em que o redator deprecia as conferências que realizavam (CARRÃO, 1889). O único veículo de imprensa vinculado a um partido monárquico que tratou com seriedade a questão republicana foi o Sete de Março, que via a República sob uma perspectiva crítica.

A difusão de ideários republicanos por meio de artigos e textos é uma forma de ação política, uma vez que, como ensina Bourdieu (2001, p. 96), os agentes que formam o mundo social têm um conhecimento desse mundo e sabem que podem

ticas. Manteve o Livre Paraná, fundado em 1883, por cinco anos, até mudar-se para o Rio de Janeiro, em 1887. Faleceu nesta cidade, em 1916 (NICOLAS, 1961, p. 20).

9 A trajetória de Eduardo Mendes Gonçalves é repleta de lacunas: sua filiação é desconhecida, assim como a data do seu nascimento. Há, contudo, fortes indícios de que tenha nascido em São Paulo. Chegou ao Paraná, em 1884, para assumir o cargo de secretário de obras públicas do governo. Casou-se com uma descendente das elites locais, e possuía ligações com Francisco Glicério e Herculano de Freitas, entre outros republicanos paulistas. Sabe-se que morreu em São Paulo, em 1911. Mais detalhes sobre a sua trajetória e sobre as redes de sociabilidade dos redatores mencionados neste artigo podem ser encontrados em Correa (2006).

10 Pude constatar tal afirmação durante a leitura dos periódicos. Ela também pode ser observada em Martins (1908) e Chaves (1990). atuar sobre ele atuando sobre a representação que os agentes fazem dele. Dessa forma, podem fazer ou desfazer grupos - e, ao mesmo tempo, as ações coletivas que esses grupos possam empreender para transformar o mundo social de acordo com seus interesses -, produzindo, reproduzindo ou destruindo as representações que formam esses grupos e que os fazem visíveis aos demais.

Tratando, portanto, do ideário republicano, ainda no momento de utopia anterior à Proclamação, o principal jornal analisado foi A República, órgão do Clube Republicano de Curitiba, que começa a ser publicado em 188611. Uma contribuição menor veio d'O Povo, de Rocha Pombo ${ }^{12}$ (Morretes, 1857 - Rio de Janeiro, 1933), do qual apenas dois exemplares foram encontrados, e do Livre Paraná, que circulava no litoral e do qual também só restam poucos indícios.

Com a Proclamação, outras folhas republicanas surgiram na cidade. Dentre elas destaca-se o Diário do Paraná, órgão da União Republicana que disputou o controle do novo regime com o grupo ligado ao A República; embora a coleção encontrada corresponda a um período relativamente curto (cerca de seis meses), ela foi qualitativamente significativa para a compreensão das disputas políticas entre os grupos. Dos periódicos analisados, o único que apresentou uma perspectiva crítica em relação à República foi o Sete de Março $^{13}$, que acabou vinculando-se ao movimento operário e que, somado às perspectivas anarquistas de Rocha Pombo, constituíram um foco tímido, mas vigoroso, de um ideário político alternativo ao conservadorismo das elites locais.

Em função do exposto, este artigo divide-se em duas partes, cindidas pela Proclamação da

11 Surge em 15 de março de 1886 e é extinto em 1930, completando 44 anos de existência. Os exemplares microfilmados disponíveis na Biblioteca Pública do Paraná (BPP) vão de janeiro de 1888 a 1930. Contudo, existem várias lacunas nos exemplares até 1893, período abrangido por essa pesquisa.

12 Autodidata, filho de professor, tornou-se jornalista ainda jovem, com 21 anos. Foi militante do partido conservador monárquico e, posteriormente, defensor do anarquismo. Diante das dificuldades que encontrou em manter-se no Paraná, mudou-se para o Rio de Janeiro em 1897, onde mergulhou no oficio de historiador e desenvolveu uma obra extensa.

13 Exemplares de 1888 a 1891, disponíveis na Biblioteca Pública do Paraná (BPP), com várias lacunas. 
República. A primeira baseia-se na pretensão exagerada de que o sistema republicano resolveria todos os problemas nacionais. Para tanto, foram utilizados algumas folhas do litoral e uma da capital, já mencionadas, cobrindo, na medida em que as fontes permitiram, um período que vai de 1879 até as vésperas da Proclamação.

O advento da República resultou numa recomposição dos quadros e numa redefinição dos projetos a partir das relações com o poder; nesse contexto, os ideários posteriores à República, que constituem a segunda parte do artigo, podem ser divididos em dois grupos. O primeiro inclui os redatores mais ligados às elites políticas e econômicas e os cooptados, para quem a retórica republicana era um instrumento da luta pelo poder, sem diferenças significativas em seus discursos. Serão abordadas as representações políticas dos dois grupos políticos que disputavam o poder no estado. No segundo grupo, há os que discordam do discurso dominante e que seguiram uma linha de pensamento político mais radical: Rocha Pombo e Justiniano de Mello e Silva ${ }^{14}$. Vale notar que, pelas reduzidas fontes sobre esses discursos (reflexo de sua posição dominada), foi necessária a utilização de fontes alternativas.

\section{O IDEÁRIO REPUBLICANO NO PERÍODO MONÁRQUICO}

Seguindo uma ordem cronológica, o primeiro periódico importante sobre a temática republicana foi $O$ Povo: órgão dedicado a causa popular, redigido por Rocha Pombo, mas que, em verdade, não pode ser caracterizado como constituinte de um ideário, pois somente dois exemplares foram encontrados. Neles, o redator reivindica direitos sociais, liberdade de consciência e de culto, casamento civil e faz severos ataques ao sistema monárquico e ao excesso de poder do Imperador: "ninguém se lhe pode opor, porque o rei é o único poder do país. Ninguém pode protestar constitucionalmente porque a pessoa do rei é sagrada, é irresponsável [...] e quando todos os brasileiros

14 O sergipano Justiniano de Melo e Silva (Laranjeiras, 1853 - Espírito Santo, 1940) formou-se na Faculdade de Direito de Recife, onde compartilhou do movimento cultural da Geração de 1870. Foi professor, filólogo, historiador, sociólogo e jornalista, além de ter concluído um doutorado em Ciências Sociais, na Universidade de Córdoba. Migrou para o Paraná em 1876, para secretariar a presidência da província. estiverem convictos de que o Brasil merece muito mais do que o Sr. D. Pedro II, então a vontade compacta terá força insuperável” (ROCHA POMBO, 1879).

Figurava no periódico também a inspiração francesa: "Que contraste entre França e Brasil! Lá - o progresso, o povo como governo, o governo sincero! Aqui - fantasmagorias e procrastinações! [...] Em França - o progresso. No Brasil - o atraso" (idem). Influenciado pelo Manifesto de 1870 , a posição do redator converge com a de alguns republicanos que militavam em partidos monárquicos do período, como Saldanha Marinho, que criam ser a evolução a melhor forma para chegar-se à República, pelo fato de o país não estar ainda "preparado": "Vejo que por enquanto, a mudança de nosso sistema de governo por um outro republicano não traz algum proveito em nosso país, ao contrário, penso que será uma calamidade. [...] Devo dizer que não quero em absoluto a república, e se desejo o seu estabelecimento, como uma forma de governo fecunda, porque põem em atividade todas as forças sociais, todas as aptidões, não o quero a não ser pela evolução natural e espontânea da vida das nações” (ROCHA POMBO, 1880). Nesse momento, afirma-se um reformista. Embora sua perspectiva política após a Proclamação siga essa linha pacifista, ela sofrerá uma mudança radical, fruto de sua desilusão com o novo regime, como veremos adiante.

Mas foi o Livre Paraná: eco republicano, em que colaboraram Nestor Victor ${ }^{15}$ e Correia de Freitas ${ }^{16}$, a primeira folha de propaganda antimonárquica de fôlego na província, durando cerca de cinco anos. Desta, apenas seu artigo de apresentação foi encontrado:

"É a voz de uma conviç̧ão profunda, o brado de uma adesão sincera que se levanta hoje para ecoar no céu virgem e límpido do Paraná.

15 Nascido em Paranaguá, em 1868, Nestor Victor dos Santos participou do movimento republicano na sua cidade desde seus primórdios (foi ele quem redigiu a ata de fundação do Clube Republicano de Paranaguá). Mais tarde, tornou-se um importante critico literário, constituindo carreira no Rio de Janeiro.

16 Manoel Correia de Freitas, nascido em Paranaguá, foi “republicano histórico”: assinou a “Declaração Republicana Paranaense”, em 1881, participou da fundação do Clube Republicano de Paranaguá, em 1887, e tinha um bom trânsito entre os republicanos do Rio de Janeiro. 
Virgem, não na concepção do princípio, não na aspiração do ideal, mas na expressão pública da idéia.

Combater o privilégio, desde o predomínio das pequenas dinastias, até o monopólio do poder hereditário, permanente, inviolável e sagrado: eis a síntese do nosso programa.

Desde que entre o futuro do povo Brasileiro e o futuro da família Bragantina, foi o interesse dinástico Português que triunfou, a democracia pura guardou no silêncio da decepção a esperança da reação.

Há 61 anos que os seus lampejos intermitentes têm reverberado no firmamento nacional, ora com explosões rudes, ora com expansões serenas.

Pois bem, seja a aparição desta folha mais uma expansão da democracia, mais um lampejo dessa intermitência.

Deixemos que a monarquia com seu dogma inviolável e sagrado insulte a liberdade e a razão.

O dogma das sociedades modernas é a soberania do povo.

Procuremos em melhor origem o fundamento dos direitos inauferíveis da nação.

Faz-se mister que o soberano coletivo, o povo, conheça seus verdadeiros interesses e fiscalize com atenção a gestão de seus negócios, para sentir quanto o elemento monárquico é incompatível com o elemento democrático.

O desgosto que se apodera dos espíritos pelo descrédito das instituições monárquicas auxiliará o fenômeno da regeneração social.

Eia! etc. etc.” (Apresentação. Livre Paraná, Paranaguá, 7.jul.1883 apud MARTINS, 1908).

Esse texto de apresentação oferece pistas da linha seguida pelo periódico. Deixa entrever, num primeiro momento, que, embora aspirações democráticas existissem e fossem desejadas pelos paranaenses, sua divulgação ainda era incipiente, ou mesmo inexistente: "virgem [...] na expressão publica da idéia”. É interessante notar que a palavra república não aparece no artigo. Se, como demonstra Orlandi (1993, p. 71), existe um "sentido no silêncio", esse pode ser lido como um "silêncio necessário”, que atravessa o texto, e que é a matéria significante por excelência, afinal a palavra não dita poderia trazer conseqüências para os que a proferissem. O programa apresentado concentra-se na crítica às instituições monárquicas e aos seus poucos privilegiados, indicando que os anseios pela mudança de regime visavam uma igualdade jurídica. Sabe-se pela história do jornal que seus redatores empreenderam uma luta contra as oligarquias do litoral, logo, desejavam livrar-se das instituições que sustentavam aquela dominação, fundadas no direito divino. $\mathrm{O}$ nome do periódico confirma essa idéia. A doutrina positivista $^{17}$ fornecia os referenciais para as suas críticas e anseios de mudança, que se traduziam em demandas por regeneração social, liberdade, igualdade e soberania do povo.

Mas foi A República o periódico de maior repercussão, por sua importância como primeira folha republicana da capital. Eduardo Gonçalves, seu redator, explicita no primeiro número as linhas editoriais seguidas pelo jornal: "Implacável contra o abuso, não regateará elogios ao bem, venha donde vier. Como norma de proceder, estabelece o Máximo às individualidades, sem deixar por isso a crítica os atos dos homens públicos. Neste caminho - ‘A República’ - procurará seguir os edificantes exemplos de dois importantes órgãos de propaganda republicana 'A Província de São Paulo' - e a - 'Federação' de Porto Alegre. As suas colunas são francas aos oprimidos de qualquer classe ou condição" (NEGRÃO, s/d, p. 125).

De fato, dezenas de artigos desses dois jornais foram publicados n'A República, apesar de, com o passar do tempo, a influência dos paulistas ter ganhado mais espaço. De qualquer forma, a vinculação explícita do clube de Curitiba a tais periódicos indica que as reivindicações daquelas províncias também os interessavam. Assim, a aliança entre paulistas e gaúchos, grupos regionais politicamente marginalizados durante o Império,

17 A noção de “doutrina positivista” presente ao longo do texto concebe, grosso modo, a idéia de República como uma superação da fase metafísica que se caracterizaria pela forma de governo monárquico, a qual, para Augusto Comte, seria superada pela sociedade positiva ou científica, em que os detentores do conhecimento científico deveriam governar. Não foi intenção do presente trabalho analisar os positivismos paranaenses, tal como Boeira (1996, p. 34), no Rio Grande do Sul, que investigou "vários positivismos, com conteúdos e funções diversas, periodizações e longevidades variáveis, públicos e áreas de atuação diferentes”. 
encontrou adeptos na província do Paraná ${ }^{18}$, que também ocupava uma posição dominada no campo político imperial. Sua situação era tão periférica que passou despercebida na análise dos estudiosos do período que atentaram para tal aliança, como Alonso (2002, p. 159): “A Federação e a Província de São Paulo veicularam o mesmo gênero de artigos e notícias, propagando doutrinas científicas e ataques ao status quo imperial. As publicações trocavam mesmo artigos. O elo principal entre os dois grupos foi Alberto Sales, companheiro de turma dos gaúchos na Faculdade de Direito”.

É preciso, portanto, buscar as razões de tais vinculações, o que exige um breve comentário sobre os periódicos reproduzidos pelos paranaenses. O jornal A Federação aparece, em 1884, como órgão do Partido Republicano, comandado por Júlio de Castilhos, e tinha como subtítulo "federação, unidade; centralização, desmembramento". Marco da história da imprensa gaúcha, teve papel político importante na queda da Monarquia, pois suas colunas refletiram alguns dos principais episódios da questão militar (SILVA, 1986, p. 150). Já A Província de São Paulo surgiu em 1875, como órgão (não-oficial) do Partido Republicano Paulista, e pertencia a Rangel Pestana e a Américo de Campos. Dizia ser de linha política independente e não vinculada ao PRP, embora seus fundadores fossem majoritariamente fazendeiros de café do Oeste Novo paulista. O jornal defendeu desde o início os interesses da elite agrária, combatendo a centralização política e administrativa imposta pelo poder Moderador ao longo do Império. Reivindicava eleições diretas para o Senado e para a presidência das províncias, a separação entre a Igreja e o Estado, a instituição do casamento e dos registros civis e a substituição progressiva do trabalho escravo pelo trabalho livre (LEAL \& SAUL, 2007). Assim, a união entre paulistas e gaúchos era estruturada em torno de um inimigo comum, a Monarquia, que representava o atraso e que deveria ser subs-

18 Um elemento importante nessa ligação certamente foi Vicente Machado, que freqüentou a Faculdade de Direito de São Paulo no mesmo período que Júlio de Castilhos, “o agenciador das relações internas à província [do Rio Grande do Sul], bem como das articulações com o Partido Republicano de São Paulo, com o qual o Partido Republicano rio-grandense atuou praticamente em parceria durante toda a década de 1880.” (ALONSO, 2002, p.157) tituída pela República, num avanço natural, necessário, científico.

Não por acaso, o jornal do Clube Republicano de Curitiba defendia, baseado na "moderna ciência política”, a República federativa. A instituição monárquica, examinada com as lentes do positivismo, era vista como uma forma de governo primitiva, na qual prevalecia a soberania de um em detrimento da de todos. A República seria a única solução possível, "natural", resultado da evolução da sociedade; único sistema de governo humano, civilizado e científico, para o qual a sociedade deveria evoluir: "As sociedades modernas devem, pois, alargar a esfera da ciência e acabar para sempre com as especulações metafísicas e religiosas" (CHICHORRO, 1888).

Além disso, o reinado brasileiro era visto como uma anomalia nas Américas, onde todos os outros países eram republicanos. À instituição monárquica era atribuída a imoralidade política, e não aos homens, afinal, "é um absurdo negar que as instituições influam nas condições sociais de um povo" (EFEITOS E CAUSAS, 1888). O grande mal estava nas instituições inadequadas, que mantinham privilégios para uma elite incapaz, que comandava os partidos monárquicos. Críticas como essas ocupavam grande parte dos artigos d'A República, para o qual as oligarquias que compunham os partidos só faziam política sentimental, movidas por paixões e ódios, elementos dos quais o Paraná precisava livrar-se. Criticavam a imensa confusão entre os partidos monárquicos, sua falta de patriotismo, de diferenciação e a inexistência de uma direção política bem definida (CHICHORRO, 1889).

Esse teor idealista presente na utopia republicana era evidente para o redator do Sete de Março, que atribuía aos republicanos uma posição cômoda, já que não participavam da ação política stricto sensu e por isso não sofriam oposições, apenas discutiam abstratamente a maior ou menor vantagem da mudança das instituições. Já os conservadores: "dávamos batalha aos grupos, às coligações, aos personagens que exploravam a boa fé popular. [...] Nós combatíamos o inimigo, que nos sitiava de perto; e os republicanos levavam as armas de encontro às paredes de um castelo fantástico” (MELLO E SILVA, 1890).

Nesse momento anterior à Proclamação, os republicanos reivindicavam a revisão da Constituição, alegando que ela não havia sido sanciona- 
da pelo povo, mas, em verdade, sua principal repulsa vinha da alta concentração de força detida pelo poder Moderador. Criticavam também o sistema eleitoral e o voto restritivo, que excluía a maioria da população do exercício da cidadania e defendiam uma consulta à nação para determinar quais reformas deveriam ser implantadas. Recorriam constantemente à idéia de que o povo estava adormecido e precisava acordar para posicionarse contra o regime que destruía a Pátria. O povo aparece nos discursos, mas não como sujeito, pois precisava ser conduzido, devido à sua incapacidade de governar.

Sob influência do positivismo, valorizavam a Revolução Francesa: tocavam a Marselhesa, recorriam à alegoria feminina, utilizavam a expressão "Saúde e Fraternidade", e comemoravam a Queda da Bastilha, a todo 14 de julho. O exemplo francês era constantemente acionado para tratar de temas como revolução, liberdades e direitos do cidadão, embora diversas vezes, na comparação entre as revoluções americana e francesa, aquela fosse vista como mais apropriada aos regimes das Américas.

Mas a principal questão era a centralização do poder monárquico, principal alvo de ataque dos redatores, certos de que a Coroa não toleraria a descentralização de que necessitavam (EFEITOS E CAUSAS, 1888). Somente o regime federativo resolveria a questão, permitindo a expansão das atividades provinciais: "estamos convencidos de que somente dentro do sistema federal republicano se poderá operar o progresso das províncias" (A CONDENAÇÃO DO SISTEMA, 1888). A nomeação de presidentes dificultava a governabilidade e a aprovação de medidas desejadas pelas elites: "Esse sistema de governo que reduz as províncias a simples fazendas, cuja administração é confiada a pimpolhos que nada entendem dos nossos negócios é um sistema supinamente absurdo, supinamente ridículo” (FOI BUSCAR LÁ, 1888).

Sob inspiração científica, viam no federalismo uma forma de viabilizar suas idéias administrativas; mais que isso, o federalismo era o grande sonho paulista, acima mesmo dos princípios republicanos. Dentre os artigos d'A Província de São Paulo publicados n'A República, chamam a atenção os de Alberto Sales, teórico do separatismo paulista, que defendia uma confederação sulista, marcada biológica e sociologicamente. No mesmo período, os membros do Clube Republi- cano de Curitiba aderiram ao manifesto, na defesa de um governo "essencialmente americano", afinal os paulistas eram referência e deveriam servir de inspiração: “em São Paulo, província heróica por excelência e mãe dileta do Paraná, o povo concorre em massa aos meetings" (A NOVA ESTRADA, 1888).

Efetivamente, os grupos envolvidos com o Clube Republicano de Curitiba queriam mais autonomia para gerir os seus negócios (principalmente a erva-mate, que, assim como o café, era voltada principalmente à exportação) e a diminuição dos impostos que reduziam drasticamente os dividendos obtidos, a fim de limitar a influência do governo nos negócios privados, o que convergia com as reivindicações de paulistas e gaúchos. $\mathrm{O}$ federalismo possibilitaria às elites um maior controle das estruturas regionais. Em suas críticas e demandas, falavam com freqüência em nome do "povo", aspecto que tem, segundo a ótica de Bourdieu (1990b, p. 184), um caráter "rentável” e que faz parte de uma estratégia de apresentarem-se como próximos e mesmo como portadores do direito de reivindicar pelo "povo".

Novamente, as limitações retóricas do discurso das elites locais são percebidas pelo jornal Sete de Março, para o qual o republicanismo d'A República era insosso, "uma amálgama de liberdade e cativeiro, de democracia e oligarquia, de flores de retórica e de aranzéis pessimistas” (MELLO E SILVA, 1888). Seu redator vinculava o movimento aos fazendeiros e questionava a pouca ou inexistente explicação sobre os traços, as características e para que serviria de fato a República. Denunciava que os republicanos recrutavam seus militantes nos partidos monárquicos, levando para dentro de sua organização os defeitos e problemas que tanto execravam. Aponta ainda para o fato de que os republicanos de Curitiba não tinham orientação científica, e deles zombava: "seria o caso de opormos ao direito divino da monarquia, o direito diabólico da república?” (idem). Com relação à idéia de que a República não seria baseada no privilégio, como era a Monarquia, rebatia com simplicidade: "Nas repúblicas há um presidente que governa durante mais ou menos espaço de tempo. Será esse um privilegiado. Há um senado em um corpo legislativo que elaboram as leis. Há magistrados temporários ou perpétuos que proferem sentenças. Há tribunais que decidem contendas entre os poderes nacionais cuja decisão é inapelável. Há finalmente quem dissolva 
câmaras, que perdoe e anistie, quem exerça o mando sob todos as suas formas e em toda a sua plenitude. São todas essas criações modalidades do privilégio republicano" (idem).

Sobre o princípio federativo, afirmava que já fazia parte da pauta conservadora paranaense, o que facilitou ao mesmo tempo uma percepção aguçada da perspectiva difundida pelos republicanos: "Federação não significa distribuição mais ou menos racional de poder; mas concentração, aumento de liberdade. A descentralização é uma questão do domínio político: a federação uma questão de ordem social” (MELLO E SILVA, 1889a). Essa observação demonstra uma fundamentação teórica diferente para pensar essa questão, que possuía para Justiniano de Mello um caráter social mais amplo do que o aspecto institucional, que se limitava a abordar o tema sob o aspecto prático de designação do estado federal.

\section{OS DEBATES REPUBLICANOS APÓS A PROCLAMAÇÃO}

Com a queda da Monarquia, algumas modificações ocorreram na organização partidária, pois o caráter federalista da República impôs a organização de partidos estaduais, que, no caso do Paraná, resultaram de uma reorganização dos partidos imperiais, agora sob nova roupagem: "Os dois maiores partidos existentes, o Liberal e o Conservador adaptam-se às novas circunstâncias. O Partido Conservador, liderado pelo Barão do Serro Azul, é na realidade, com seu consentimento, chefiado por Vicente Machado ${ }^{19}$. Transformou-se no Partido Republicano Federal. Os antigos liberais, sob o comando do Dr. Generoso Marques dos Santos, fundam a União Republicana do Paraná” (VARGAS, 1970, p. 116).

A reorganização partidária do campo político paranaense contava com a condução dos mes-

19 Vicente Machado da Silva Lima (Castro, 1860 - Curitiba, 1907), de família tradicional paranaense, formou-se pela Faculdade de Direito de São Paulo, em 1881. Foi uma das principais figuras da cena política regional na virada do século XIX para o XX. Atuou pelo Partido Liberal até 1888, quando migrou para o Republicano. Após a Proclamação, uma aliança entre os ex-conservadores do estado e os republicanos aglutinou-se em torno de Vicente Machado. Fundaram, posteriormente, o Partido Republicano Federal, enquanto os liberais aglutinaram-se em torno de Generoso Marques dos Santos, criando a União Republicana do Paraná. mos influentes personagens, detentores do capital político acumulado durante o período imperial. Contudo, o equilíbrio de poder foi alterado com o novo regime, colocando as elites tradicionais paranaenses numa posição dominada ante a burguesia ervateira, ou, então, com o predomínio quase absoluto do Partido Republicano Federal sobre a União Republicana. O elemento-chave dessa guinada foi o alinhamento dos ex-conservadores com o Clube Republicano de Curitiba, apoiado pelo PRP.

O Partido Republicano Federal ${ }^{20}$ tinha como figura política central Vicente Machado e era composto pelos republicanos que militavam em torno do Clube Republicano de Curitiba, aliados aos exconservadores. Estes deram início a um vasto discurso de unificação de todos aqueles que desejassem participar da reorganização da pátria, incluindo os membros dos ex-partidos monárquicos. As alianças foram firmando-se, e uma nova configuração de forças, formada por republicanos e exconservadores, passou a ocupar as estruturas de poder do estado, que tinha A República como seu órgão oficial.

A União Republicana do Paraná surgiu formalmente em março de 1890, quando as forças políticas do estado começaram a reorganizar-se. Foi composta majoritariamente por antigos liberais e alguns republicanos históricos que ficaram fora do jogo político com a ascensão do grupo de Vicente Machado ao poder. Com isso, os ex-liberais e alguns republicanos históricos do litoral foram alijados da participação no campo do poder local e decidiram compor um partido de oposição, a União Republicana, que tinha como órgão na imprensa o Diário do Paraná.

A própria forma como se deu essa reorganização das forças políticas locais deixa entrever que as lutas apreendidas no campo do discurso eram menos ideológicas do que pessoais, intra-elites. Quase todos os redatores do período que trataram da questão republicana estiveram envolvidos direta ou indiretamente com esses dois jornais, que, por sua semelhança, constituem o primeiro

20 A data formal do aparecimento desse partido no Paraná não foi encontrada. Sabe-se, no entanto, que o Partido Republicano Federal de São Paulo, cujo mentor foi Francisco Glicério, foi fundado em 1893. Estiveram vinculados à vertente paulista do PRF Eduardo Gonçalves, Vicente Machado e Ubaldino do Amaral. 
grupo de ideários políticos a ser analisado já no período republicano, em que permaneceram em voga as idéias positivistas e as propostas de descentralização política.

Os discursos que divergiam dessa linha foram produzidos por dois personagens que ocupavam posições bastante periféricas, e representam as escassas tentativas de subversão da ordem hegemônica conservadora. Dessa forma, serão analisados, num segundo momento, a perspectiva crítica que Justiniano de Mello e Silva desenvolveu sobre a forma republicana recém-instaurada, assim como sua adesão à República Socialista, e o anarquismo de Rocha Pombo.

IV. A REPÚBLICA E DIÁRIO DO PARANÁ: POSITIVISMO, FEDERALISMO E REPÚBLICAELITISTA

A discussão a respeito dos ideários republicanos dos membros do Clube Republicano (futuro Partido Republicano Federal) e da União Republicana, representados respectivamente pelo $A R e$ pública e Diário do Paraná, foi reunida em um único item pela semelhança teórica e de prática política dos dois grupos. Logo, percebe-se que suas disputas eram eminentemente o reflexo de uma luta pessoal pelo poder, e não de concepções antagônicas ou divergentes de República, até porque os dois aspectos centrais das transformações pretendidas estavam presentes nas idéias dos dois grupos: federalismo e positivismo. Este último é mais forte e presente em ambos, como justificativa da exclusão do povo das decisões e na defesa dos militares, disputados pelos dois grupos, que acataram e defenderam a legitimidade da ditadura. Dessa forma, a intenção é traçar os pontos comuns que apontam para um ideário de República e mostrar as diferenças pontuais e retóricas presentes no jogo político das elites locais. A análise dos manifestos políticos dos dois grupos reforçará tal proximidade de concepção.

A panacéia republicana tomou conta dos periódicos, que caracterizavam o governo provisório como "verdadeiramente democrático" e "severamente honesto" (A REPÚBLICA, 1890a), motivo pelo qual todos deveriam unir-se, pois qualquer reorganização dos partidos seria lida como uma oposição: "Sendo porém a política do governo provisório, assentada sobre princípios científicos e esteada nos mais elevados intuitos patrióticos, para que não auxiliá-lo na hercúlea tarefa?” (A REPÚBLICA, 1890b).
O Clube Republicano adota o discurso da unidade, afirmando aceitar os elementos dos velhos partidos, desde que se resignassem a ocupar uma posição subordinada: "Somos complacentes para com os vencidos. Queremos a união de todos debaixo da bandeira republicana" (A REPÚBLICA, 1889a). O discurso, à primeira vista unificador, tem, na verdade, uma pretensão de impor uma visão legítima do mundo social, determinando as suas divisões e a construção dos grupos (BOURDIEU, 1990a, p. 165). Os redatores do jornal insistiam muito nesse tipo de discurso, semanticamente vazio, mas que tem muito a dizer a respeito da luta simbólica pela demarcação das posições no campo político, sob o argumento de que a reorganização do país deveria ser conduzida por republicanos e militares que trabalharam pela substituição do governo.

Fruto de tal contexto e fundamentado nesse discurso unificador, formou-se, nos primeiros meses de regime, uma composição única com os governistas, resultado do período inicial de indefinições, o que já demonstra certa homogeneidade dos ideários políticos. O discurso de união era tão forte que mesmo o grupo ligado à União Republicana reproduzia-o, referendando a idéia de que naquele momento só deveria haver um partido, "porque o governo provisório tem tido o apoio quase unânime do exército, dos republicanos históricos e dos órgãos dos antigos partidos que já se tem declarado ante o novo estado de coisas" (VICTOR, 1890a), o que era uma afirmação contraditória com a própria realidade de estarem constituindo-se como partido.

Como se sabe, a Proclamação da República foi, na prática, resultado de uma articulação entre militares e republicanos. Essa configuração repetiu-se no campo político local, em que a reverência e o respeito aos militares tornaram-se objeto de disputa entre os grupos d'A República e do Diário do Paraná. O exército participou ativamente dos movimentos cívicos do final do século XIX na província e influenciou a disseminação de doutrinas positivistas, inspiradas em Augusto Comte. Assim como no seu periódico de referência, A Federação, o jornal do Clube Republicano de Curitiba publicou diversos artigos sobre a questão militar e freqüentemente os convocava a ficar ao lado do povo e lutar contra o despotismo monárquico. Após a Proclamação da República, a exaltação aos militares tomou proporções ainda maiores, sendo considerados "símbolo do 
republicanismo americano”: "O povo brasileiro, não contava como não contará por muitos anos ainda, com forças próprias, educadas e representadas em maioria, que possam operar por si nas revoluções arriscadas. Em todas as nações está no militarismo a solidariedade e pacificação sociais [...] Oh! Meu Deus, quanta ingratidão pérfida com o desconhecimento dos mais comezinhos fundamentos de uma instituição que representa o caráter nacional! [...] Somos republicanos extremados e com orgulho o mais fervoroso nos declaramos adeptos sinceros e leais do exército brasileiro, porque estamos convencidos que todas as glórias da pátria, todas as evoluções que temos sentido e observado pacificamente refletem-se nessa heróica legião, símbolo do republicanismo americano" (A REPÚBLICA, 1890c).

O elemento militar teve peso significativo na balança do poder local, influenciando-a conforme as coligações que efetivavam, tendo ficado no início junto ao grupo do Diário do Paraná, que tinha também o apoio de algumas associações de imigrantes e do Clube dos Operários, formando um grande conglomerado de insatisfeitos e desejosos de participar na condução política do novo regime. Por isso, diminuíam a importância dos republicanos que estavam no poder, ao colocar a revolução de 15 de novembro como obra dos militares, que foram afastados, pelos republicanos "exclusivistas”, da condução do governo, deixando evidente o motivo da aliança, e mesmo contradizendo uma afirmação anterior de que a adesão dos militares à União Republicana teria sido fruto de sua opção pelo grupo mais "sincero".

Cabia, de acordo com A República, aos "republicanos sinceros”, eleger Marechal Deodoro o primeiro presidente republicano brasileiro: "O bravo Marechal Deodoro, chefe do governo provisório e o homem que com o maior desprendimento o estabeleceu, não é simplesmente o candidato natural à presidência da República dos Estados Unidos do Brasil, é o centro obrigado para onde convergem todas as vistas da Pátria” (MACHADO, 1890a). Esses motivos fizeram com que o apoio d'A República à candidatura de Deodoro fosse visto como puro oportunismo por seus adversários políticos (VOLTAM POR SEREM RUINS, 1890). A leitura conservadora da ditadura republicana, que, na teoria comtiana, era a opção para a transição à sociedade positiva, influenciou a simpatia pela ditadura militar de Deodoro da Fonse- ca, embora originalmente a doutrina positivista repudiasse os governos de sabre. Por questões de apoio político e sustentação no poder, o grupo do Clube Republicano via o governo provisório como legítimo e necessário, e os militares como defensores do progresso paranaense, motivo pelo qual deveriam ser eleitos pelo "povo": "principais responsáveis pela estabilidade da instituição republicana [...] foi essa ilustre classe abnegada que evitou que a aspiração nacional se afirmasse por sangrentas revoluções [...] extremos defensores do progresso paranaense [...] Agremiem-se todos em torno dos nomes dos distintos militares apresentados aos sufrágios das urnas paranaenses [...] e demonstrarão a sua dedicação à causa da República” (A REPÚBLICA, 1890d).

A defesa da soberania popular é outra constante nos artigos, e ela deveria ser exercida por meio da representação, como na República norteamericana. Os positivistas consideravam os jacobinos (defensores da participação direta) metafísicos e defensores de um tipo de liberdade - de participação - que não servia para o mundo moderno: "todos os homens que devassam os campo da ciência abstrata ou que difundem os segredos de suas aplicações concretas, são os supremos magistrados, que conferem a soberania popular [...] [esta] deve curvar-se diante do mestre-escola [...]. A ninguém é permitido eximirse da obrigação fundamental de previamente preencher as condições de competência, antes de ser o portador de sua opinião política. Pretender que o povo pode, sem preparo, decidir das mais transcendentes questões sociais, como a paz e a guerra, a constituição da família e da propriedade, da justiça e das finanças, é simplesmente deslocar para o povo a ficção que fazia a fortuna dos reis, é voltarmos ao direito divino, que conferia a onisciência e a impecabilidade ao soberano de nascimento [...]. É um dever de patriotismo compreenderem todos, hoje, que não há soberano de espécie alguma, que dispense a sagração pelo mestre-escola” (ORDEM E PROGRESSO, 1889).

Referendam aqui a permanência da restrição à cidadania e o caráter paternalista que perpassava a discussão sobre soberania e participação popular. Percebe-se também a recorrência da ideologia do mérito, que se daria com o fim dos privilégios monárquicos, mas que de fato ampliaria o espaço de participação das elites letradas. A idéia de que a soberania popular poderia manifestar-se por meio 
do voto das municipalidades também foi defendida, como forma de evitar a anarquia e o apelo às massas desqualificadas ${ }^{21}$ : " $E$ é por isso que tão legítimo resultado dessa soberania pode ser a eleição de governador, representante do poder executivo, pelas municipalidades, como pelos representantes do Congresso Legislativo, ou ainda por eleitores especiais sufragados para esse fim. [...] Na escolha de alguns destes sistemas de eleição do Chefe de Estado, o que se procura, o que se cogita é o modo mais ou menos democrático dessa escolha, e que melhor acentue a vontade popular, evitando a anarquia. O voto decreto do povo, na eleição de governador, é por certo o meio mais democrático da manifestação da soberania, mas é sistema que não esta escoimado de inconvenientes, máxime quando se tem que lutar com a falta de educação cívica em todas ou em algumas camadas populares. A eleição por meio de representantes do Congresso, pelas municipalidades ou por eleitores especiais escolhidos para esse fim, pode ser um meio de corrigir defeitos em dadas circunstâncias e os inconvenientes que surgem de um apelo direto à massa popular. Essa idéia por certo animou o autor do projeto a fazer a escolha do sistema de eleição pelas municipalidades e talvez, tendo ainda em vista que com a eleição desse modo não ficaria sem representação parcela alguma da soberania popular. E isto porque as municipalidades são representantes diretas do elemento popular” (MACHADO, 1890b).

Não menos influenciados pelo positivismo, os membros da União Republicana também defendiam a importância de a República ser baseada na ciência e de seguir as orientações da "política moderna”. A representação da ditadura também era positiva, embora com a ressalva de que estaria durando mais do que o esperado. Diziam defender a verdadeira democracia (em oposição aos seus adversários), pois nela a vontade popular manifestar-se-ia real e diretamente por meio da representação.

Exemplo de tal divergência retórica foi a criação, pelos redatores do Diário do Paraná, de uma divisão do mundo social por meio da classificação de dois tipos de republicanos: os “unionistas”,

21 O Sete de Março posicionou-se contra a eleição do governador mediante o voto das municipalidades, sob o argumento de que o poder Executivo estadual não é parte nem prolongamento do poder municipal. que agiam para que a República fosse de todos os brasileiros, e os "exclusivistas", que evitavam a participação dos ex-membros do Partido Liberal - a participação do povo nem sequer é mencionada. A dominação do Partido Republicano Federal teoricamente não deveria ocorrer, pois: “Grande parte, quase a unanimidade do partido liberal uniuse á parte de republicanos de mérito mais real, e os conservadores, com muitas exceções, uniramse a outros republicanos, a que, si faltava prestígio sobrou arte para se apoderarem do governo e deixar este Estado nas tristes condições em que o vemos” (OS PARTIDOS POLITICOS, 1890).

A divisão criada buscava deslegitimar simbolicamente os republicanos que estavam no poder, por terem se aliado de maneira oportunista aos conservadores, o que teria levado à política de exclusão dos liberais. Essa nova configuração de dominação do grupo d'A República não se institucionalizou sem resistências, gerando intrigas, perseguições e acusações.

Em abril de 1890, cogitou-se que a Constituição fosse votada por plebiscito, o que num primeiro momento causou repulsa aos membros do Clube Republicano: "Em absoluto, somos contrários ao regime plebiscitário, e só circunstâncias muito especiais podem aconselhar esse apelo direto ao povo". Embora esse sistema tivesse por base resoluções votadas diretamente pela população, "fonte exclusiva de todos os poderes, só excepcionalmente a intervenção direta popular por meio de plebiscito deve ocorrer”. No final, o redator faz uma concessão ao plebiscito, desde que apresentasse à votação os aspectos que mais lhes interessavam: "De modo que se o projeto de constituição for inquestionavelmente a consubstanciação das necessidades do país, se ela representar o princípio democrático de federação, se a independência dos poderes, seus limites, se estabelecerem de conformidade com os princípios e necessidades do regime republicano; - seremos pelo plebiscito” (A REPÚBLICA, 1890e).

A mesma posição, com as mesmas justificativas, era defendida pelos membros da União Republicana, que, embora desejassem que o país entrasse no regime definitivo por meio de uma Constituinte, aceitaram o plebiscito desde que em determinadas condições, e mesmo o decreto da Constituição: "Assim, pois, embora fosse com a convocação da Constituinte que se poderia agir de um modo mais regular, embora nós não acom- 
panhemos no seu temor aqueles que se receiam de anarquia com essa convocação; si este for o pensamento do governo, venha a Constituição por um decreto, que nós nos daremos por satisfeitos, opinando mais por este outro, em vista dele evitar embaraços e delongas que possa haver, e de entrarmos desde já no período definitivo e normal” (VICTOR, 1890b).

Poucos dias depois, o redator retifica: "Nós fomos sempre da opinião de que o preferível era que a constituição não passasse por plebiscito nem fosse decretada pelo governo provisório mas sim que ela nos viesse de uma constituinte" (NÃO ERA BALELA, 1890). Logo, os grupos concordavam com a exclusão do povo, embora se valessem de artifícios retóricos diferentes, não havendo, portanto, diferenças ideológicas substantivas entre eles.

Esses argumentos encontravam fundamentos no positivismo, que não concebia os homens como iguais, de fato, uns aos outros, o que explica também a grande quantidade de representações de que a República foi obra de homens fortes, corajosos e abdicados. A igualdade, como direito fundamental, reside no direito de todos os cidadãos terem a sua dignidade respeitada, afirmou Comte, no livro IV do Sistema de filosofia positi$v a$. Mas isso não significa que os homens sejam parecidos nem que o sejam fisicamente, quem dirá no campo psicológico, intelectual e moral, em que as desigualdades são ainda mais pronunciadas (LINS, 1965, p. 204-205). Essa constatação acerca das desigualdades subjacentes entre os homens levou Comte a conceber o sufrágio universal como "uma doença social” e por isso a soberania popular deveria manifestar-se por intermédio dos magistrados. É preciso destacar, contudo, que ele não se cansou de reconhecer a importância histórica do dogma da soberania, no sentido de enfatizar a subordinação dos poderes sociais ao bem de toda a sociedade e aos seus interesses gerais.

O positivismo também foi acionado para justificar a República federativa, considerada para esse grupo de republicanos paranaenses a forma de governo que melhor adaptava-se às condições do Brasil, e a que melhor atenderia aos seus interesses. Repudiavam a forma unitária francesa, por ser o Brasil um país muito extenso, e também por almejarem a construção de uma suposta identidade e autonomia latino-americana: "Sigamos o espírito novo que impele ao progresso. A América tem inspirações próprias, e já não precisa ver o que se fez ou faz na Europa; Deixemos de ser o prolongamento das monarquias européias para sermos o povo republicano, da América republicana, ligando-nos a todos os países do novo continente por um laço de estreita solidariedade e de mútuo respeito" (A REPÚBLICA, 1889b). Embora o grupo da União Republicana tenha discorrido pouco sobre o tema da federação, eram também críticos do sistema centralizador: "Todas as nossas esperanças pelo futuro estão postas na idéia de que se vai transformar esse estado de coisas, com uma verdadeira descentralização que se inicie no país" (A QUESTÃO DOS BANCOS REGIONAIS, 1890).

\section{OS MANIFESTOS}

As semelhanças entre os grupos fica patente também na análise de seus manifestos políticos. Tanto o manifesto de Vicente Machado (A República) quanto o de Correia de Freitas (Diário do Paraná) são políticos, stricto sensu, na medida em que tratam da cena local e da perspectiva dos grupos e não de reflexões teóricas. Destacam suas lutas pelo poder, não tendo qualquer pretensão de divulgação de doutrina ou de valores ideológicos. Em verdade, estão disputando uma versão dos fatos. Novamente nota-se aqui que ambos queriam a união das forças e lutavam pelo apoio e simpatia do exército. O próprio redator do Diário do Paraná tinha noção da similitude do pensamento dos dois grupos: "Pois bem, as suas próprias palavras transcrevemos nós, como a tradução legítima do nosso modo de pensar, - o que não admira que ainda ontem fomos companheiros: si hoje acontece, ainda, uns e outros assim dizermos a mesma coisa, é porque nós continuamos por onde íamos e eles ainda falam pelo hábito, simplesmente por ele, que na ação eles se mostraram uns vitoriosos indignos dos troféus que lhes couberam e da simpática bandeira que defendemos" (VICTOR, 1890c)

Intitulado “Ao Estado do Paraná”, o manifesto do Clube Republicano foi publicado em três partes, durante o mês de março de 1890 . Na primeira, assinou apenas Vicente Machado; na última, subscreveram Eduardo Gonçalves, Vicente Machado e mais três personagens locais. Trata-se de um discurso que constrói uma versão dos fatos atinentes à República e aos republicanos no Paraná e que busca legitimar simbolicamente as divisões que estavam processando-se no campo político 
paranaense. O redator do manifesto chega a afirmar que o momento não era propício a teorias, pois a preocupação central deveria ser a paz e a conciliação dos "bons elementos".

$\mathrm{O}$ texto aponta que a sociedade passava por um “estado especial”, devido à revolução de 15 de novembro. Como o Paraná contava com poucos republicanos, os méritos pela República deveriam ser localmente atribuídos ao sacrifício e à abnegação dos poucos que por ela militaram: "Não tínhamos nomes feitos na política; o humilde signatário destas linhas apenas [Vicente Machado], por circunstâncias especiais, tinha no cenário acanhado da política provincial adestrado armas e se encaminhado na luta investido do mandato de deputado da ex-província”.

No entanto, segundo o manifesto, foi essa defasagem numérica que fez com que a desordem tomasse conta, pois as ambições não patrióticas dificultavam a reorganização da pátria, o que trouxe sérios e duros encargos para os "evangelizadores republicanos”. Por isso, para o Clube Republicano, aquele momento não deveria ser utilizado para disputas políticas fundadas em ódios e ressentimentos, mas para uma política reconciliadora, sendo que os membros dos ex-partidos monárquicos teriam que esquecer as antigas disputas e unir-se em torno do "desejo de reorganizar a pátria”. A idéia de uma suposta união dos republicanos com os adeptos sinceros tinha como intenção reduzir simbolicamente a participação dos liberais e dos membros da União Republicana, representados como aqueles "movidos por ódios e paixões".

Por sua vez, o manifesto que fundou a União Republicana do Paraná era intitulado "Manifesto político do cidadão Manoel Correia de Freitas", datado de sete de abril de 1890, e publicado alguns dias depois (FREITAS, 1890). Correia de Freitas, que se autodenominava um republicano social-democrata, começa o texto com o mesmo argumento de Vicente Machado, dizendo que infelizmente na maioria dos estados havia poucos republicanos, particularmente no Paraná, e que estes devem sacrificar-se para reconstruir a pátria. A partir de então, dá mostras claras de que os manifestos representavam uma luta pelo poder político e pelo mito fundador do republicanismo local, na medida em que ambos relatavam os fatos que levaram à Proclamação a partir de sua ótica, limitando-se a narrar fatos e a descrever posições formais de poder. Por isso, o Manifesto da União Republicana reconta como se deram os primeiros momentos da República no Paraná, destacando, para justificar a cisão com o Clube Republicano, o surgimento viciado da comissão executiva do Partido Republicano, pelo apoio que recebeu do então governador do estado. Tal fato em pouco tempo teria suscitado uma forte oposição, o que levaria o grupo d'A República a aliarse aos conservadores do período monárquico.

A partir de então, Correia de Freitas reclama que todos os cargos foram direcionados para essa nova configuração de forças, deixando de fora os liberais, ao que o Manifesto do Clube Republicano responde: "Pretendiam por ventura, aspirar os liberais preferência de confiança entre os seus correligionários e os nossos? Seria essa aspiração legitima?” Mesmo assim, insiste que não houve exclusivismo nas nomeações: "não somos exclusivistas, mas previdentes” (idem).

Mas, segundo Correia de Freitas, o grupo d'A República deixou de fora o exército, verdadeiro exemplo de civismo e abnegação, e que tinha direito de participar ativamente da reconstrução da pátria. Apresenta então os preceitos que sustentam a União Republicana, repletos de generalidades, baseados numa "política séria e fraterna, vazada nos moldes democrático-sociais os mais avançados, em cujo mecanismo governamental a liberdade seja uma verdade, e a intervenção direta e legitima do povo, nos públicos negócios, torne-se permanente. E, pelos nossos antecedentes históricos, pela nossa etnologia, pelos nossos hábitos e costumes, pela identidade de clima, solo, flora, fauna, crenças, aspirações, cultura, indústrias, pelas legítimas relações de parentesco e pelas estreitas relações comerciais, entendo que o Paraná tem necessidade absoluta de fazer de hoje em diante uma política de união sulista, com os seus co-irmãos os estados de Santa Catarina e Rio Grande do Sul". Assim, acredita que "passaremos a ser respeitados como uma força verdadeira a agir dentro da federação brasileira e não olhados, como até agora, com certo pouco caso pelo governo geral” (idem).

Percebe-se que a união com os estados do sul exclui São Paulo, principal parceiro do outro grupo. De qualquer forma, ambos viam nas alianças regionais a possibilidade de melhorar a posição ocupada pelo Paraná no campo nacional. Enquanto isso, os signatários do manifesto do Clube Repu- 
blicano afirmavam que continuariam na neutralidade da direção política, que só poderia ser conduzida pelos republicanos para que não houvesse uma quebra da calma. Percebe-se que a união dos "bons elementos" implica um processo de estigmatização política dos liberais, que ficam com uma representação carregada de adjetivos negativos, dificultando a sua participação no jogo político local.

Assim, embora dotados de várias similitudes, incluindo o fato de que ambos os redatores tinham capital simbólico e o reconhecimento de seus grupos, o Clube Republicano era um grupo mais institucionalizado e dotado de maior capital para impor uma ordem simbólica (BOURDIEU, 2001, p. 46), que só funcionou por reunir condições sociais exteriores à lógica do discurso, quais sejam, posições formais e informais de poder. Por outro lado, os membros da União Republicana constantemente reiteravam que eram "pela união e contra o exclusivismo" (OS PARTIDOS POLITICOS, 1890), semelhante ao argumento dos membros d'A República, o que demonstrava que se valiam - em seus discursos destinados a subverter a ordem de que eram vítimas - dos princípios de divisão lógica que fundavam essa mesma ordem (BOURDIEU, 2001, p. 99-100), tornando-a, dessa forma, impossível de ser aniquilada.

\section{AS PROPOSTAS ALTERNATIVAS: SOCIA- LISMO E ANARQUISMO NA TERRA DOS PINHEIRAIS}

Para além do discurso das elites, apenas duas vozes dissonantes tiveram alguma reverberação no campo político local e apresentaram perspectivas distintas e por demais revolucionárias para a sociedade paranaense de então. Apesar de pouco expressivas, são indícios de que houve tentativas de subversão da ordem discursiva dominante, tentativas provenientes de jornalistas eloqüentes e detentores de alto capital cultural. O primeiro deles, Justiniano de Mello e Silva, foi, durante o Império, um declarado monarquista e não participou da propaganda republicana, criticando-a em seus principais aspectos. Sociólogo, dotado de um apurado senso de crítica social, percebeu rapidamente os rumos que o novo regime tomava. Nesse ínterim, aproximou-se do recém-criado Clube Operário e ali encontrou uma causa compatível com o seu habitus radical, engajando-se na divulgação de propostas de integração política e social dos artistas e operários no sistema republicano.
O segundo discurso de contestação aparece por meio da figura de Rocha Pombo, um dos primeiros republicanos paranaenses. Decepcionado com a ditadura militar e com as atrocidades que dela decorreram - ele era antimilitarista - aproximou-se do movimento anarquista e, no bojo das agitações dos primeiros anos republicanos, defendeu esse sistema na imprensa e em suas obras de ficção.

Em verdade, uma observação rígida dessas idéias não permitiria situá-las como republicanas stricto sensu. Todavia, elas inseriam-se num contexto de debates e disputas por uma concepção de regime político e, no caso do socialismo, de forma compatível com o movimento republicano em sua "defesa dos princípios clássicos da igualdade e da fraternidade, o que só se realizaria pela inserção do povo numa ordem econômica e política” (GOMES, 1988, p. 49). Vale notar que no Paraná não foi encontrado um grupo que defendesse uma República liberal, nos moldes de Silva Jardim, o que poderia constituir um meio termo entre as propostas conservadoras das elites e as radicais populares.

\section{CRÍTICA SOCIAL DA REPÚBLICA DOS FAZENDEIROS E PENSAMENTO SOCIA- LISTA EM CURITIBA}

Mesmo antes da Proclamação, o redator do Sete de Março questionava a forma como os republicanos concebiam o novo regime como solução para todas as querelas nacionais. Sua formação científica e erudita, que incluía um Doutorado em Ciências Sociais na Argentina, refletiu-se em suas análises políticas, que destoam da maioria dos redatores locais por seu caráter de crítica social e por seu repertório culto. Por isso, seu discurso funciona como um contraponto aos ideais conservadores das elites.

Embora não tivesse militado pela República, esperava que ela trouxesse melhorias para a situação do povo brasileiro, apesar de não compartilhar do discurso salvacionista proferido pelos republicanos. Por isso, não aderiu imediatamente, como a maioria de seus companheiros, à República e ao governo provisório, preferindo observar e analisar o processo que se delineava. Justiniano optou por engajar-se no movimento operário, aproveitando-se também das indefinições iniciais na condução do novo regime que deram espaço para o surgimento de uma série de propostas políticas, das mais conservadoras às mais radicais. A causa 
operária passou a ser desde então seu espaço de investimento político, incitando por meio do seu jornal a tomada de consciência das classes oprimidas na luta por uma sociedade igualitária, firmando-se assim como um grande crítico da República conservadora que se montava. Para tanto, valia-se da sátira para ironizar a panacéia republicana que acreditava num milagre a ser operado pelo novo regime: "Estão aí a dizer que o velho monarca, deposto, fartou-se de devorar preás, que a república guardaria intactas para opulentar os festins da democracia. Em outros termos afirmase que o ex-imperador corrompeu muitos homens que o novo regime preservaria da mácula hedionda” (MELLO E SILVA, 1889b).

Relativizou e desconstruiu também, ao longo dos seus artigos, a representação da Coroa como o grande mal nacional, não por negar os problemas do regime, pois admitia que "era uma feira para a ganância”, e isso por culpa daqueles que a sustentavam: "Nossa imprevidência, que tinha a face sempre voltada para o erro e os olhos sempre cerrados para a verdade. Foi o egoísmo, a indiferença, a vaidade [...] que nos tornava nulos para todas as peleja do direito, submissos a todas as tiranias”. Não compartilhou, portando, da perspectiva positivista que via a Monarquia como sinal de atraso e pivô de abusos e privilégios do poder e a República como uma etapa necessariamente mais avançada do desenvolvimento social: "Hoje como ontem, entendemos que a monarquia não é responsável dos abusos e desatinos que desacreditaram o regime decaído [...]. Que a República venha rejuvenescer uma geração decrépita, de onde se destacou apenas uma classe verdadeiramente forte; que a Revolução triunfante na praça pública penetre nos costumes e derrube os preconceitos ainda vigentes; que os atuais dominadores sejam tão grandes no fastígio do poder, como nós fomos sinceros na humildade dos nossos esforços é o que cordialmente desejamos, em bem da pátria, aos criadores e responsáveis das instituições nascentes" (MELLO E SILVA, 1890a).

O problema para ele não estava na instituição monárquica, mas no domínio pernicioso que as oligarquias locais exerciam sobre todo o país: "Nunca imputávamos ao trono todo esse cortejo de torturas sofridas pelo povo, sob domínio das oligarquias provinciais. Estas eram as causas do martírio popular” (MELLO E SILVA, 1890b). Criticava a falta de coerência histórica dos republi- canos, que acreditavam que a mudança das instituições seria capaz de mudar abruptamente a conduta dos homens: "Afirma-se que os antigos partidos sucumbiram ao lado do trono: que novas agrupações devem substituir aquelas que estrebucham sob os escombros da velha instituição monárquica, que a reconstrução nacional se operará rápida como o desaparecimento do antigo regime, hoje amaldiçoado pela maioria da nação. Não alimentamos ilusões, nem vamos construir no vácuo como os ideólogos. O presente e o futuro serão sempre um prolongamento do passado embora em via de transformação; os homens de hoje terão as mesmas deformidades, curtirão os mesmos males e sofrimento, padecerão das mesmas insônias e sobressaltos que atormentavam os nossos antepassados. A política republicana não é um talismã, que realize a identidade física dos contrários, ou um elixir que transmuta às vísceras humanas faculdades estupendas" (idem).

Escreveu artigos bastante irônicos que buscavam construir outra representação da Monarquia e da realidade republicana, ainda em 1889, quando a "opinião pública” encontrava-se ainda extasiada com o novo regime, o que aponta para uma forte autonomia de pensamento e posicionamento. Criticou a falta de ideologia dos seus ex-correligionários, que rapidamente afirmavam-se em perfeita conformidade com um sistema que teoricamente colocava-se como radicalmente contrário a tudo que vigorava até então, "sob a mascara de intransigentes adeptos da liberdade”. O novo governo havia absorvido conservadores e liberais que se confraternizavam "em torno da imaculada vitória” (idem).

Justiniano de Mello construiu um discurso heterodoxo e para tanto se valeu também de seu repertório de historiador, a fim de criticar a inobservância, por parte dos republicanos, de questões históricas básicas, pois estes acreditavam na possibilidade de construir um novo regime sem a devida observação das condições sócio-históricas, como ensinava a tão recorrida doutrina positivista. Segundo o redator, "uma idéia sem passado é uma idéia sem futuro" e a negação desse preceito faria com que fatalmente tivessem de admitir seus erros: “Terão de reforçar os processos da sua lógica quando forem impressionados por fatos idênticos no domínio da república. O governo, se é um produto, vale também como sintoma para o diagnóstico das enfermidades sociais” (idem). 
O redator do Sete de Março foi também um crítico da sociedade brasileira, valendo-se de análises sociológicas para refletir sobre o privilégio, a igualdade, a liberdade e a participação popular. Para Justiniano, o Estado que se apóia numa classe privilegiada enfraquece-se, pois prejudica todas as outras que são negligenciadas. Nesse contexto, não é possível falar de vontade popular, afinal só há um grupo favorecido, como no caso brasileiro, em que o interesse econômico e político da classe agrícola "pesa opressivamente, e subordina à sua nefasta influência todos os outros grupos sociais" (MELLO E SILVA, 1889c). Este tipo de leitura destoa do rol de discursos observados e já apresenta os indícios teóricos que sustentaram a sua aproximação e defesa de demandas sociais de inclusão e participação da classe operária.

O Clube Operário de Curitiba, fundado em janeiro de 1890, era composto por artistas e operários e, "se a França era o principal espelho para a República, a Alemanha o era para o partido operário” (GOMES, 1988, p. 50). O do Paraná não fugiu a essa regra e também se inspirou nas conquistas das classes operárias alemãs, embora estas não devessem servir de postulado: "Entretanto, no momento mesmo em que homens de alta capacidade contestam a existência de um proletariado brasileiro, como se este não vivesse onde viveu a escravidão - uma classe numerosa se agita neste estado, e pela primeira vez propõe aos poderes públicos a solução de um problema social” (MELLO E SILVA, 1890b).

Para o redator, apesar de o direito do trabalho não ter no Brasil o mesmo significado que tinha nos países de civilização avançada, "há um direito ferido pela legislação e uma reivindicação justa aos olhos da igualdade democrática [...]. No Brasil só é inviolável o direito de nada fazer" (idem). Os argumentos utilizados apontam para um grupo em processo de formação, não por iniciativa própria, mas incitados por lideranças que defendiam a inclusão social e política desses não-cidadãos, mediante um discurso que pretendia mudar o mundo social, mudando a representação social acerca desse mundo (BOURDIEU, 2001, p. 97).

Em abril de 1890, seu jornal adotou o subtítulo Órgão de reformas sociais, vinculando-se ainda mais às idéias socialistas. O movimento operário, em Curitiba, buscava transformar-se num partido, mas, enquanto isso não se realizava, somava forças à União Republicana, elegendo o redator do Sete de Março representante do operariado na disputa para a Constituinte estadual.

Cabe lembrar que houve inicialmente duas facções do movimento socialista no Brasil, cujo berço foi o Rio de Janeiro. O Sete de Março dialogava com $O$ Paiz e, portanto, com o grupo liderado por Vinhaes, que contou com mais adesões do que o de França e Silva. Como não existia uma estrutura organizacional de trabalhadores no Brasil daquele período, isso possibilitava a união das concepções socialistas a uma concepção de República, já que o novo regime tinha como objetivo realizar a igualdade e a fraternidade por meio da inserção do povo na ordem política e econômica (GOMES, 1988, p. 47-49).

Para Justiniano de Mello, faltava preparo intelectual aos miseráveis que ainda não tinham se dado conta dos problemas deixados pela escravidão, suas injustiças e a inoperância da noção de igualdade. A classe estava muito dispersa e não possuía intuitos e aspirações comuns, o que facilitava a submissão dos fracos aos poderosos e tornava difícil a organização de uma força ativa e inteligente que atuasse sobre a inércia da minoria depositária da influência política.

Mesmo com influência limitada, esse tipo de posição é significativa e reflete uma tentativa consistente de subversão política, vinculada a uma subversão cognitiva, que incita a uma reconversão da divisão do mundo proposta pelas elites. A crítica herética de Justiniano de Mello quer um mundo sem divisões - ou ao menos um em que os trabalhadores sejam atores e participem da ordem política.

\section{ROCHA POMBO: DESILUSÃO E ANAR- QUISMO}

A idéia de apresentar a perspectiva anarquista de Rocha Pombo tem a intenção de apontar para discursos que divergiam daqueles dominantes. Deveras radical, a temática anarquista foi pouco abordada pela grande imprensa do período e, quando tratada, aparecia de maneira hostil e preconceituosa, contribuindo para que "o imaginário da população fosse associando o anarquismo com assassinato, desordem e preguiça" (VALENTE, 1997, p. 141), pois as elites tinham aversão a tais concepções, por seu caráter excessivamente subversivo. Rocha Pombo, que já estava numa posição marginalizada politicamente e profundamente desiludido com os rumos da República, 
adere aos ideários anarquistas, a princípio demonstrando simpatia, nas colunas do jornal que redigia, pelo líder Giovani Rossi, e também em seu romance Petrucello, em que critica a sociedade capitalista e afirma a sua utopia anarquista ${ }^{22}$. Posteriormente, na fase em que morou no Rio de Janeiro, envolveu-se ainda mais com o movimento, afinal, "no bojo do desencanto com a pouca ou nenhuma sensibilidade do novo regime para as reformas democratizantes, surgiram as propostas anarquistas, trazendo alternativas radicais para a organização política do país” (CARVALHO, 1987, p. 25).

Em 1892, era proprietário do Diário do Comércio e havia um ano que a Colônia Cecília havia se instalado em Palmeira, Paraná. Esta passava por uma série de dificuldades, assim como os imigrantes em geral, em decorrência de boicotes do governo, que prometia incentivos para a imigração, mas que estava em dívida com colonos polacos e italianos, os quais se sublevaram. $\mathrm{Na}$ tentativa de desvincular o evento na colônia e seu chefe, Rocha Pombo afirma que "é falso esse boato porque acha-se à frente de seus confrades o digno Dr. Giovani Rossi, home ilustrado, prudente e incapaz de concitar os colonos a qualquer distúrbio" (ROCHA POMBO, 1892a).

Como havia pouco espaço para que as idéias anarquistas fossem debatidas ${ }^{23}$, Rocha Pombo direcionou para as obras de ficção suas perspectivas e desilusões políticas, afinal, conhecia o conservadorismo e o limitado espaço para propostas que ultrapassassem o posicionamento conservador das elites locais. Dessa forma, recorremos a essa narrativa alternativa, na forma da sua obra ficcional intitulada Petrucello, publicada nesse período da virada para a República. Trata-se, pois, de um claro exemplo de produção simbólica que reflete um posicionamento político.

Seu processo de desencantamento com a política é evidente na narrativa que conta a trajetória de Petrucello, um italiano - não por acaso -, que, incomodado com o crescimento do capitalismo,

22 No Hospício, romance simbolista publicado em 1905 pela Garnier, tem como temática principal o delírio e a loucura, por meio dos quais nasce a utopia anarquista.

23 Segundo Valente (1997, p. 17), não existia nenhum debate sobre a Colônia Cecília nos Anais da Câmara e da Assembléia estadual entre 1890 e 1920. parte rumo ao Oriente. No meio do caminho, faz uma parada no Rio de Janeiro, onde encontra um conhecido, no momento em que a República acaba de ser proclamada, e, apesar de sentir-se exilado, acaba inserindo-se no mercado literário local. O personagem tinha uma percepção essencialmente negativa das transformações ocorridas no país: "É um absurdo supor que a facilidade com que nas repúblicas os homens de todas as classes podem exercer a sua ambição constitui uma prova de excelência da instituição republicana. Hoje em todo o mundo, especialmente nas repúblicas agitadas da América Latina, a política é um vício pior do que os outros vícios que se conhece" (ROCHA POMBO, 1892b, p. 80).

O romance marca a posição do seu autor, crítico da política e da luta partidária: “A política especialmente é o grande mal da América. Em alguns países discute-se mesmo ainda a forma de governo, e em outros o sistema republicano é deturpado pelos maus costumes públicos e pelos desregramentos dos partidos políticos” (idem, p. 81-82). Parte da responsabilidade vinha do militarismo: "Uma das questões que mais devem impressionar o espírito de todos os pensadores e dos governos, é a necessidade da abolição da guerra e das instituições militares. O exército é hoje uma força desperdiçada, um fardo inútil com que lutam os povos - e isto quando não é ainda o espantalho da liberdade e da paz” (idem, p. 70).

A narrativa da obra insere tais transformações políticas num processo mais amplo de modernização, que levou o homem a uma degradação moral e à completa desorientação da sociedade, deslumbrada com a ciência e a indústria. O protagonista, exilado ante a modernidade, martirizado pela vida burguesa e saudoso das tradições e da vida em comunidade, concebe, numa de suas obras literárias, a utópica "Cidade dos Homens": "Esta cidade seria dirigida por homens sábios que estariam tomados pelo espírito do século. Os sábios aboliram a figura de Deus, como desnecessário e afrontoso à dignidade humana. Obcecados pela sua crença cega nas leis, as elaboram perfeitas, incluindo desde liberdades políticas até os serviços públicos. Estabelece-se um governo extremamente organizado, capaz de influir na vida dos cidadãos. Surge um problema, porém: as leis não são obedecidas. Apesar da criação de novas penas e fóruns para julgar aqueles que não cumprem ou não fazem cumprir a lei, a situação per- 
siste. Diferentes grupos passam a lutar pelo poder, abalando as 'forças do país'” (Rocha Pombo apud QUELUZ, 1994, p. 93).

Na seqüência, um estrangeiro destrói esse argumento, explicando que o caminho da liberdade e da felicidade não está na lei, e sim na consciência de todos. O sistema penal é abolido e a lei passa a ser a da consciência de cada um. O ideal apresentado no livro é bastante proveitoso para pensar a posição de Rocha Pombo perante as questões do seu tempo. O modelo da nação ideal positivista foi apresentado e, logo em seguida, criticado pelo autor, que acredita que um governo de cunho autoritário levaria a uma guerra civil. Surge, então, o messias, que reorganiza a sociedade nos únicos termos em que valeria a pena: Deus e a consciência de cada um, sendo que o Estado aparece como um ente do qual a sociedade deveria libertar-se: "Há de nascer por força, como mais racional e mais lógica, a tendência que já se constata mesmo entre alguns pensadores para atenuar o mais possível a influência do Estado, se não for coisa que se possa conseguir a eliminação dessa influência” (Rocha Pombo apud VICTOR, 1979, p. 70).

Rocha Pombo enuncia a possibilidade de salvação da sociedade por meio de uma utopia libertária, sugerindo a abolição do Estado, dentro dos moldes do pensamento anarquista. Fiç̧ão e realidade confundem-se na narrativa do escritor, entusiasta do anarquismo e representante de uma parcela pequena, mas vigorosa, de contestadores da ordem hegemônica.

\section{CONCLUSÕES}

A leitura de todos esses discursos mostra que os grupos dominantes, interessados na manutenção do statu quo, investiram num discurso político, teoricamente imparcial e neutro, que, embora filiado a uma linha nacional, estava direcionado para as lutas locais. Conclui-se, portanto, que as disputas intra-elites não diziam respeito a uma luta entre a ortodoxia e a heterodoxia no campo político.

Além disso, o modelo federalista de inspiração norte-americana que defenderam não levava em consideração as diferenças sociais entre o Brasil e os Estados Unidos, e "nessas circunstâncias, o liberalismo adquiria um caráter de consagração da desigualdade, de sanção da lei do mais forte" (CARVALHO, 1990, p. 25). Tinham uma atitude ilus- trada, pois falavam em nome do "povo", mas de forma vaga e abstrata, e não para o povo (COSTA, 1999, p. 264). Por mais que houvesse um desejo, estavam muito distantes de conseguir implantar, no plano da prática, os elementos liberais que utilizavam retoricamente, pois lhes faltava uma base social para ações mais radicais.

Esses grupos que detinham o controle majoritário da produção simbólica reproduziam um discurso oficial que pregava liberdade, igualdade e fraternidade, com vistas à ordem e ao progresso. Não estavam preocupados com questões de cidadania e participação popular, mas sim com o caráter cosmopolita de seu aburguesamento, reflexo de sua atenção direcionada especialmente para a legitimação da nova organização política.

As perspectivas de subversão da ordem dominante ficaram por conta de grupos que não tinham capital político suficiente para alterar as estruturas de poder e modificar as configurações do campo político paranaense, como no caso do anarquismo e do socialismo. Parafraseando Bourdieu, a aceitação social do discurso não se reduz à sua gramaticalidade, pois os locutores desprovidos de competência legítima ficam excluídos dos universos sociais em que esta se exige, ou então condenados ao silêncio (BOURDIEU, 2001, p. 29). No entanto, esses discursos são historicamente importantes na medida em que foram os únicos que tentaram subverter a ordem estabelecida, configurando uma resistência que garantiu a permanência de certos espaços de pensamento e liberdade mais livres de coações (RODRIGUEZ LÓPES, 2002, p. 117).

A análise dos discursos republicanos mostra que a política paranaense, no final do século XIX, era mais um resultado de alianças e desavenças entre grupos do que fruto de posicionamentos ideológicos. Os discursos serviam, majoritariamente, como armas retóricas utilizadas para orientar o enfrentamento intra-elites, movido pelo desejo de participação, o que fez com que tivesse um caráter genérico alicerçado na concepção do fim dos privilégios, embora sem a ampliação da cidadania. Houve pouco espaço para o debate de outras idéias e concepções de regime que não fossem os desejados pelas elites, que, "vencedoras", consolidaram-se no poder, encontrando as condições ideais para a implantação dos seus projetos de modernização conservadora do estado. 
Amélia Siegel Corrêa (ameliac@terra.com.br) é Mestre em Sociologia pela Universidade Federal do Paraná (UFPR) e Doutoranda em Sociologia pela Universidade de São Paulo (USP).

\section{REFERÊNCIAS BIBLIOGRÁFICAS}

ALONSO, A. 2002. Idéias em movimento : a geração de 1870 na crise do Brasil Império. São Paulo : Paz e Terra.

BOEIRA, N. 1996. O Rio Grande de Augusto Comte. In : DACANAL, J. \& GONZAGA, S. $R S$ : cultura \& ideologia. Porto Alegre : Mercado Aberto.

BOURDIEU, P. 1990a. Espaço social e poder simbólico. In : BOURDIEU, P. Coisas ditas. São Paulo : Brasiliense.

1990b. Os usos do "povo". In : BOURDIEU, P. Coisas ditas. São Paulo : Brasiliense.

2001. ¿Qué significa hablar? Economía de los intercambios lingüísticos. Madrid: Akal.

2003. O poder simbólico. Rio de Janeiro : B. Brasil.

CARRÃO, B. 1889. A propaganda republicana. Gazeta Paranaense, Curitiba, 17.jan., p. 1-2.

CARVALHO, J. M. 1987. Os bestializados : o Rio de Janeiro e a república que não foi. São Paulo : Companhia das Letras.

1990. A formação das almas : o imaginário da República no Brasil. São Paulo : Companhia das Letras.

1996. A construção da ordem : a elite política imperial. Teatro de sombras : A política imperial. Rio de Janeiro : UFRJ.

CHAVES, M. 1990. A centenária república e o Coronel Joaquim Monteiro. Curitiba : Vicentista.

CHICHORRO, J. 1888. A origem dos governos. A República, Curitiba, 21.dez., p. 2.

1889. Editorial. A República, Curitiba, 17.ago., p. 1.

CORRÊA, A. 2006. Imprensa e política no Paraná : prosopografia dos redatores e pensamento republicano no final do século XIX. Curitiba. Dissertação (Mestrado em Sociologia). Universidade Federal do Paraná.

COSTA, E. 1999. Da monarquia à República : momentos decisivos. São Paulo : UNESP.

FIGUEIRA, A. 1948. Como se fez a propaganda da República em Paranaguá. Palestra pronunciada em agosto de 1948 na Rádio Difusora Paranaguense. Paranaguá.

FREITAS, M. 1890. Manifesto Político do Cidadão Manoel Correa de Freitas. Diário do Paraná, Curitiba, 22.abr., p. 1-2.

GOMES, A. 1988. A invenção do trabalhismo. Rio de Janeiro : IUPERJ.

2002. A República no Brasil. Rio de Janeiro : Nova Fronteira.

HOLLANDA, S. B. 1985. História geral da civilização brasileira. T. II : O Brasil monárquico. V. 5 : Do Império à República. São Paulo : Difel.

LEAL, C. \& SAUL, V. 2007. O Estado de São Paulo. In : ABREU, A. A.; BELOCH, I.; LATTMAN-WELTMAN, F. \& LAMARÃO, S. T. N. (cords.). Dicionário histórico-biográfico brasileiro pós-1930. 2a ed. Rio de Janeiro : Fundação Getúlio Vargas.

LINS, I. 1965. Perspectivas de Auguste Comte. Rio de Janeiro : São José.

MACHADO, V. 1890a. Editorial. A República, Curitiba, 23.mai., p. 1.

. 1890b. Editorial. A República, Curitiba, 16.dez., p. 2.

MARTINS, R. 1908. Catálogo dos jornaes publicados no Paraná : 1854-1907. Curitiba : Paranaense.

MELLO E SILVA, J. 1888. O nosso amanhã de hoje. Sete de Março, Curitiba, 28.nov., p. 1.

1889a. Agitação política. Sete de Março, Curitiba, 29.jun., p. 2.

1889b. O privilégio. Sete de Março, Curitiba, 30.nov., p. 1.

1889c. Reformas sociais. Sete de Março, Curitiba, 14.dez., p. 1.

1890a. Notas e fatos. Sete de Março, 
Curitiba, 11.jan., p. 4.

1890b. Voto de louvor. Sete de Março, Curitiba, 14.jun., p. 1.

NEGRÃO, F. s/d. Efemérides paranaenses. Edição comemorativa do 20o aniversário do CEB. Curitiba : s/n.

NICOLAS, M. 1961. Cem anos de vida parlamentar : deputados provinciais e estaduais do Paraná. Curitiba : s/n.

ORLANDI, E. 1993. As formas do silêncio : no movimento dos sentidos. Campinas : UNESP.

QUELUZ, G. 1994. Rocha Pombo : romantismo e utopias (1880-1905). Curitiba. Dissertação (Mestrado em História). Universidade Federal do Paraná.

ROCHA POMBO, J. F. 1879. Noticiário. O Povo, Morretes, 06.dez, p. 3.

.1880. Editorial. O Povo, Morretes, 19.dez., p. 2.

1892a. Colônia Cecília. Diário do Comercio, Curitiba, 22.dez., p. 1. 1892b. Petrucello. Curitiba : Paranaense.

RODRÍGUEZ LÓPEZ, J. 2002. Pierre Bourdieu : sociología y subversión. Madrid : La Piqueta.

SILVA, J. 1986. Breve histórico da imprensa sulrio-grandense. Porto Alegre : Corag.

VALENTE, S. 1997. A presença rebelde na cidade sorriso : contribuição ao estudo do anarquismo em Curitiba, 1890-1920. Londrina: UEL.

VARGAS, T. 1970. O indomável republicano. Curitiba : O Formigueiro.

VICTOR, N. 1890a. Artigo. Diário do Paraná, Curitiba, 14.mai 12.mai.

1890b. Artigo. Diário do Paraná, Curitiba, .1890c. Artigo. Diário do Paraná, Curitiba, 8.mai.

. 1979. Rocha Pombo no Paraná. In

A obra crítica de Nestor Victor. Rio de Janeiro : Fundação Casa de Rui Barbosa.

\section{OUTRAS FONTES}

A condenação do sistema. 1888. A República, Curitiba, 23.jan.

A nova estrada. 1888. A República, Curitiba, 18.jun.

A questão dos bancos regionais. 1890. Diário do Paraná, Curitiba, 11.jun.

A República. 1889a. Editorial. Curitiba, 3.dez., p. 1.

1889b. Editorial. Curitiba, 19.dez., p. 1. 1890a. Editorial. Curitiba, 20.jul., p. 1. . 1890b. Editorial. Curitiba, 8.fev., p. 1. . 1890c. Editorial. Curitiba, 23.fev., p. 1. . 1890d. Editorial. Curitiba, 10.jul., p. 1. 1890e. Editorial. Curitiba, 9.abr., p. 1.

Efeitos e causas. 1888. A República, Curitiba, 15.jan.

Foi buscar lá. 1888. A República, Curitiba, 3.abr.

Não era balela. 1890. Diário do Paraná, Curitiba, 30.jun.

Noticiário. 1886. Gazeta Paranaense, Curitiba, 18.mar., p. 3.

Ordem e progresso. 1889. A República, Curitiba, 29.nov.

Os partidos políticos. 1890. Diário do Paraná, Curitiba, 15.mai.

Voltam por serem ruins. 1890. Diário do Paraná, Curitiba, 21.mai. 
JUSTICE PÉNALE AUTORITAIRE ET LA CONSOLIDATION DE L’ÉTAT PUNITIF AU BRÉSIL

\section{Débora Pastana}

La transition démocratique brésilienne, toujours en cours, affronte des difficultés énormes pour y intégrer l'action pénale. Il y a plus, les bornes au processus de démocratisation établis dans l'action de ce secteur étatique nous renvoient à l’idée selon laquelle le champ juridique est devenu imperméable aux changements démocratiques. Même si le discours actuel chez les professionnels du Droit proclame la démocratisation de la Justice Pénale, on remarque, en fait, une forte résistance du champ juridique à assumer sa responsabilité politique à l'égard de la consolidation démocratique. Cet article présente des analyses et des conclusions formulées à partir des remarques sur la Justice Pénale brésilienne et qui ont originé le mémoire intitulé « Justice Pénale au Brésil actuel : discours démocratique - pratique autoritaire ». L'objectif de cette recherche fut de réflechir sur la politique criminelle contemporaine, tournée vers l'élargissement de la répression et au recours à l’incarcération. Une telle politique, menée au Brésil après l'ouverture politique survenue en 1985, s'adapte au projet libéral qui est aussi en cours dans le pays et dans presque tout l'occident capitaliste. Comme on le remarque, la Justice Pénale, même pendant l'accomplissement de la peine, opère de façon autoritaire et excluante, quand elle élimine au maximum les droits prévus par la loi à l'égard des criminels condamnés, en adoptant une attitude fort répressive, qui se revèle par les infimes pourcentages d'avantages accordés. Donc, au Brésil, les réponses à la criminalité souvent consistent en des peines sevères, traduites dans le manque de respect aux garanties constitutionnelles et dans le recours excessif à l'incarcération. Dans cette ligne, nos gouvernements démocratiques contemporains adoptent souvent une position punitive visant réaffirmer la capacité de l'État de punir et contrôler la criminalité.

MOTS-CLÉS : contrôle pénal ; incarcération ; démocratie en tutelle ; État punitif ; Sociologie de la Violence.

\section{PRESSE POLITIQUE ET PENSÉE RÉPUBLICAINE DANS L’ÉTAT DU PARANÁ À LA} FIN DU XIXÈME SIÈCLE

\section{Amélia Siegel Corrêa}

La crise du régime monarchique brésilien fut suivie de l'avènement et de l'expansion du mouvement républicain, à la fin du XIXème siècle. Dans cette période, la presse non seulement est devenue la scène des débats institutionnels, mais encore a joué le rôle de pouvoir informel, lié au gouvernement et à l'organisation des partis. Il s'agissait d'une presse d'opinion, ayant comme l'un de ses axes les commentaires partisans. Les colonnes des journaux servaient à écrire de façon anonyme ce qu'on ne pouvait dire publiquement à l'Assemblée Législative, au Sénat ou dans la Chambre des Députés, ce qui constituait un forum de discussion alternatif à la tribune. Cet article cherche à reprendre les modèles de République qui ont circulé dans ces magazines de l'état du Paraná, les mettant en rapport aux configurations dans lesquelles ils étaient incorporés et à la position qu'ils occupaient dans le domaine du pouvoir local et national. Néanmoins, il faut se souvenir que les idéaux républicains prédominants ne se sont pas répandus sans résistance dans l'état du Paraná ; au contraire, ils ont été détectés et combattus sur place, mais sans assez de force politique. Nous nous appuyons sur la perspective bourdieusienne selon laquelle les discours ne sont pas uniquement signes destinés à être compris et déchiffrés, mais qu'ils sont également indices de statut, qui voudraient être valorisés et appréciés, et d'autorité, à être reconnus et obéis, puisqu'ils constituaient un objet de lutte symbolique pour le pouvoir. L'analyse des discours républicains montre que la politique de l'état du Paraná à la fin du XIX ${ }^{\text {ème }}$ siècle était plutôt des résultats des alliances et des désaccords entre groupes que le fruit de position idéologique. Les discours servaient, généralement, à être des armes rhétoriques utilisées pour orienter l'affrontement inter-élites, poussé par le désir de participation, ce qui lui a 
donné une caractéristique générale, appuyée sur la conception de fin de priviléges, néanmoins sans l'élargissement de la citoyenneté.

Mots-clés : républicanisme ; Paraná ; presse politique ; fédéralisme ; groupe politique.

PRODUCTION LÉGISLATIVE ET CONNEXION ÉLECTORALE DANS L’ASEMBLÉE LÉGISLATIVE DE L'ÉTAT DU PARANÁ

\section{Emerson Urizzi Cervi}

L'article intègre les travaux portant sur les relations entre l'arène politique législative et l'arène politique électorale, dénommées « connexion électorale ». L'objectif est d'analyser les interactions entre ces deux arènes dans un système de représentation politique sous-national : le législatif de l'état du Paraná. À partir de cette relation entre la production législative individuelle des députés dans la 14ème législature de l'Asemblée Législative de l'État du Paraná (ALEP) et la performance électorale de ceux qui disputent la réélection, on cherche à identifier des éventuels résultats électoraux des candidats à la réélection. À cet effet, outre les résultats électoraux des candidats à la réélection, qui ont donné naissance à une typologie du vote (aussi bien concentrée ou non concentrée au niveau de la région) comme variable dépendante, trois ensembles de variables explicatives sont compris dans le modèle. Le premier est formé des variables sur la position politique institutionalisée (groupe auquel on appartient ; idéologie ; parti politique ; exercice de fonction auprès de la présidence de l'assemblée ; nombre de mandats à l'ALEP ; et position à l'égard de thème polémique). Le second porte sur la visibilité du mandat (nombre d'apparitions des parlementaires dans le principal journal quotidien de l'État et genre d'apparition). Le troisième groupe de variables explicatives concerne la production législative individuelle (type de projet de loi proposé ; portée géographique du projet de loi ; portée sociale du projet de loi ; nombre de projets proposés ; et nombre de projets adoptés pendant le mandat). À partir de l'intersection des variables composant le modèle en tests d'indépendance de moyennes et de regressions, le modèle analytique montre que l'existence d'un grand rapport entre les votes concentrés dans la région et une plus grande probabilité de réélection. Les variables explicatives sur la position politique et la visibilité du mandat se sont avérées faibles en ce qui concerne l'explication pour le type de vote, alors que certaines variables sur la production législative individuelle ont présenté un taux élevé de rapport avec le vote régional et, par conséquent, avec une plus grande possibilité de réélection du parlementaire.

MOTS-CLÉS : connexion électorale ; députés de l’état ; production législative ; état du Paraná. 
constitutional rights and ample recourse to incarceration. In this vein, our contemporary democratic governments have frequently adopted a punitive stance that seeks to reaffirm the State's aptitudes for punishing and controlling criminality.

KEYWORDS: penal control; incarceration; democratic tutelage; punitive State; Sociology of Violence.

\section{POLITICAL JOURNALISM AND REPUBLICAN THOUGHT IN LATE $19^{\mathrm{TH}}$ CENTURY} PARANÁ

\section{Amélia Siegel Corrêa}

The crisis of the Brazilian monarchical regime was accompanied by the emergence and expansion of the republican movement at the end of the 19th century. During that period, the press not only became the stage of institutional debates but also had the role of an informal power, linked to the government and political party organization. It was a press that expressed opinions and created a space for partisan commentary. Newspaper columns were used to anonymously air that which could not be expressed publicly in the Legislative Assembly, the Senate or the House of Representatives, thus constituting an alternative tribune for debate. This article seeks to give voice to the different republican models that circulated within these state of Paraná newspapers, relating them to the configurations they were a part of and with the position that they held within local and national fields of power. Furthermore, it is important to recognize that the dominant republican ideas were not disseminated without resistance: rather, they were heard and combated at the local level, although efforts in this regard remained lacking in political force. Our analysis incorporates the Bourdieusian perspective according to which discourses are not only signs to be understood and decoded but also status indicators - seeking to be validated and evaluated - and forms of authority, seeking to be believed and obeyed; in both cases, object of struggles over symbolic power. Analysis of republican discourse shows that Paraná state politics of the late 19th century was more a result of alliances and tensions between groups than the fruit of clear ideological stands. Discourses served mostly as rhetorical weapons which were used to orient intra-elite conflict, moved by the desire for participation. This gave them a generic character, based on a notion of putting an end to privilege without widening citizenship rights..

Keywords: Republicanism; Paraná state; political journalism; federalism; political field.

\section{LEGISLATIVE PRODUCTION AND ELECTORAL CONNECTION IN THE PARANÁ STATE LEGISLATIVE ASSEMBLY}

\section{Emerson Urizzi Cervi}

This article belongs to a field of work that deals with the relationships between the legislative political arena and electoral politics, relations that have been referred to as "electoral connection". Our goal is to analyze the interaction between these two arenas within a system of sub-national political representation: the Paraná state legislature. Through looking at the relationship between the individual legislative action of state representatives within the 14th legislative period of the Paraná State Legislative Assembly (Assembléia Legislativa do Paraná (ALEP)) and the legislative performance of those who ran for re-election we seek to identify possible interdependence between individual parliamentary activity and re-election. For these purposes, in addition to putting together a voting typology on electoral results for candidates seeking re-election (looking at whether voting is regionally concentrated or not as dependent variable), our model also includes three sets of explanatory variables. The first is made up of variables regarding institutionalized political position (parliamentary group affiliation, ideology, political party, position occupied within the legislature, number of ALEP mandates served and position on polemic issues). The second looks at the visibility of the mandate (number of 